by the appropriate government department or by the respective national universities. Students from other African countries may also be admitted to the programme. It is planned that students will do their course work at Makerere, go back to their own countries for field research, and return to Makerere for writing up.

\title{
History of the Kingdom of Warri, Nigeria
}

Mr. J. O. E. SAGAY of Warri is to visit Bahia, Rio de Janeiro, Lisbon, and Rome (where there are missionary archives) to gather material for a detailed history of the Warri kingdom. His research will be assisted by the Warri Land Trust which is responsible for supervising Itsekiri land under the Chairmanship of Professor Origse Thomas of the Lagos University Teaching Hospital.

\section{R. E. Bradbury Memorial Appeal}

THE appeal for a prize fund in memory of the late Dr. R. E. Bradbury, which was launched a year ago, has produced contributions totalling $£^{6} 7^{2} \cdot 99$. The appeal committee, consisting of Professor J. D. Fage, Professor Daryll Forde, Dr. P. C. Lloyd, Professor A. F. C. Ryder, and Professor M. G. Smith, has divided this sum into three equal parts which have been presented to the three institutions with which Dr. Bradbury served during his career as a social anthropologist-University College, London, the University of Ibadan, and the University of Birmingham. This will enable each of them to establish a R. E. Bradbury Memorial Prize to be presented annually for outstanding work by their students in the fields to which Dr. Bradbury had himself so notably contributed.

\section{Grants-in-Aid for Preparation of Oral Data Collections}

IN order to encourage the scholarly presentation of oral data collections for deposit, the African Studies Association (U.S.A.) has, through the generosity of the Ford Foundation, been able to give a limited number of grants-in-aid to assist with the necessary costs in time, informants, and materials. Further information may be obtained from the African Studies Association, 2 I 8 Shiffman Center, Brandeis University, Waltham, Mass. o2 I 54.

\section{Index to African Periodical Literature}

Compiled by the Library of Congress African Section, Africa South of the Sahara: Index to Periodical Literature $1900-1970$ is a four-volume work, published in 1971 by G. K. Hall \& Co., Boston, Mass., at $\$ 260$ the set. Most references pertain to articles published during the last ten years in the major scholarly journals of Africa, Asia, Europe, and North America. The arrangement of the Index is by area and by subject within areas. The subjects covered include the humanities, social sciences, African literature, law, natural sciences, etc.

'African Archives'

African Archives is a series of files on the history of Africa. Each file portrays a particular period or subject and contains a selection of documents drawn from historical recordsmaps, drawings, tables, photographs, and narrative text. The format, which was devised in Zambia, enables readers to build up their own archives system by adding notes, photographs, and press cuttings to individual files. Each file is complete in itself. They will be of special interest to senior school and university students. File I, entitled 'Safari' contains a selection of documents on East Africa's history, with particular emphasis on the nineteenth century.

The series is published by Oxford University Press, P.O. Box 2335, Lusaka, and the National Education Company of Zambia (NECZAM), P.O. Box 2664, Lusaka. 